\title{
RNA Synthesizing Activities and Glucocorticoid Binding Capacities in Thymus Cells during Rat Development
}

\author{
K. LIPP(37) AND N. VAN DER MEULEN \\ Universitäts-Kinderklinik, Marburg, West Germany
}

\begin{abstract}
Summary
This investigation was designed to study specific glucocorticoid binding to cytoplasmic fraction and nuclei of thymus cells during rat development and to find out whether these data can be correlated to changes of RNA synthesizing activity of nuclei and cytoplasm. The dexamethasone binding capacity of cytoplasm rose rapidly in rats weighing up to $125 \mathrm{~g}$ and decreased significantly in animals weighing more than $160 \mathrm{~g}$. Hormone binding to nuclei revealed similar but less pronounced changes. RNA synthesizing activity of nuclei measured by $\left[{ }^{3} \mathrm{H}\right]$ uridine incorporation in vitro decreased from $57 \pm 4.6 \mathrm{dpm} / \mu \mathrm{g}$ DNA in young to $23 \pm 2.2 \mathrm{dpm} / \mu \mathrm{g}$ DNA in adult rats. RNA synthesizing activity of the cytoplasmic fraction fell $21.6 \%$ and that of purified polymerase $\mathrm{II}_{\mathrm{B}}$ fell $27.8 \%$ during development. Inhibition of RNA synthesis by dexamethasone applied in vivo and in vitro showed age-dependent differences. The RNA synthesizing capacity of nuclei was inhibited up to $39 \%$ in animals weighing $130 \mathrm{~g}$ and only $9 \%$ in aging rats. Similar changes were observed by incubation of intact thymocytes with and without hormone. The observed inhibitory effect of dexamethasone on RNA synthesis is well correlated to changes of cytoplasmic hormone receptor capacities during development.
\end{abstract}

\section{Speculation}

If the observations on developmental changes of hormone binding capacities and on age-dependent responses of thymus cells to glucocorticoid action can be applied in general, it is not the hormone itself, but the receptor concentration which seems to be the limiting factor for the cellular response to the hormone action. Therefore, efforts should be made to find ways to induce synthesis of these receptor proteins.

Binding of steroid hormone to specific protein receptors is essential for steroid hormone action. Glucocorticoids are known to affect a variety of different tissues. Proteins which specifically bind glucocorticoid hormones have been identified in these tissues, e.g., in liver $(4,13)$, in thymocytes $(20,24)$, and in lymphocytes $(3,23)$. It is generally accepted that the first step in steroid hormone action is the combination of the hormone with a specific cytoplasmic protein receptor. The cytoplasmic steroid receptor complex is then taken up by the nucleus and bound to specific acceptor sites. This interaction is believed to initiate the characteristic hormone response, presumably by alteration of DNA template activity.

The response of the tissue to glucocorticoid action is hormone and organ specific. In case of lymphatic cells glucocorticoid action results in a mainly antianabolic change of intracellular metabolism, like inhibition of synthesis of proteins (15), DNA (10), and RNA (8) and finally in cytolysis (25). In lymphosarcoma (11) and liver cells (6) the alteration of metabolism by steroids is proportional to the concentration of intracellular hormone receptor. In contrast to steroid-sensitive call lines, steroid-resistant cells have little or no hormone binding capacities. In view of this functional role we studied the dexamethasone binding capacity of the cytoplasmic fraction and of nuclei of thymus cells during rat development. Changes in hormone binding should be correlated to an altered response of the tissue. Therefore, we measured nuclear RNA synthesizing activity and also the DNA-dependent RNA polymerase $\mathrm{III}_{\mathrm{B}}$ in cytoplasm that controls synthesis of tRNA (7), and the inhibition of RNA synthesis by dexamethasone in whole cells and purified nuclei during rat development.

\section{MATERIALS AND METHODS}

Han-Wistar rats were obtained from the Institut für Versuchstierzucht (26); animals which weighed less than $50 \mathrm{~g}$ were of either sex, heavier rats were male. $\left[5-{ }^{3} \mathrm{H}\right]$ Uridine $5^{\prime}$-triphosphate $\left(\left[{ }^{3} \mathrm{H}\right] \mathrm{UTP}\right)$, specific activity $14 \mathrm{Ci} / \mathrm{mmol}$, and [1(2)${ }^{3} \mathrm{H}$ ]dexamethasone, specific activity $28 \mathrm{Ci} / \mathrm{mmol}$, were purchased from The Biochemical Center (27). McCoy 5-A medium was obtained from Gibco (28), Dextran T500 from Pharmacia (29), DE-cellulose from Whatman Biochemicals Ltd. (30), calf thymus DNA and TC 199 from Serva (31), and Scintigel from C. Roth (32). All other chemicals were purchased from Merck (33) and Boehringer (34). Toluene scintillation fluid contained $5 \mathrm{~g}$

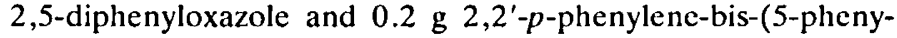
loxazole) in 1 liter of toluene.

The rats were killed by cervical dislocation, and the thymus dissected out rapidly and weighed. Glands were minced with scissors in TSS buffer $(0.25 \mathrm{M}$ sucrose, $0.025 \mathrm{M} \mathrm{KCl}, 0.01 \mathrm{M}$ $\mathrm{MgCl}_{2}$ in $0.067 \mathrm{M}$ Tris- $\mathrm{HCl}, \mathrm{pH} 7.55$ ), filtered successively through four and eight layers of cheese cloth, and centrifuged at $150 \times \mathrm{g}$ for $10 \mathrm{~min}$ at $4^{\circ}$. All further steps were made at $4^{\circ}$.

\section{ISOLATION OF THYMUS CYTOPLASM}

For estimation of dexamethasone binding capacity thymocytes were homogenized in TSS buffer in a glass-teflon homogenizer. The crude nuclei were sedimented at $400 \times g$ and the supernatant was centrifuged at $105,000 \times g$ for $60 \mathrm{~min}$ in the $50 \mathrm{TI}$ rotor of a Spinco ultracentrifuge. The soluble postmicrosomal supernatant was used after removal by suction of material which floated. In further experiments thymocytes were allowed to swell in $1.5 \mathrm{mM} \mathrm{MgCl} 2$ for $5 \mathrm{~min}$ before homogenization. Isotonicity was reconstituted by addition of concentrated TSS buffer.

\section{ISOLATION OF NUCLEI}

Sedimented crude nuclei were purified by centrifugation through a 2.2 and $2.4 \mathrm{M}$ discontinuous sucrose gradient at $95,000 \times g$ for $90 \mathrm{~min}$.

\section{ASSAY OF SPECIFIC STEROID BINDING}

Aliquots of thymus cell cytoplasmic fraction were incubated with $5 \times 10^{-8} \mathrm{M}\left[{ }^{3} \mathrm{H}\right]$ dexamethasone for $2 \mathrm{hr}$ at $4^{\circ}$, with or 
without $25 \times 10^{-5} \mathrm{M}$ nonradioactive dexamethasone. After incubation $0.5-\mathrm{ml}$ portions were mixed with $0.5 \mathrm{ml}$ dextrancoated charcoal suspension $(3.75 \mathrm{~g}$ charcoal and $0.375 \mathrm{~g}$ dextran in $100 \mathrm{ml} 0.01 \mathrm{M}$ Tris- $\mathrm{HCl}, \mathrm{pH} \mathrm{8.0)}$ and incubated for $10 \mathrm{~min}$ at $4^{\circ}$. Duplicate tubes were centrifuged for $2 \mathrm{~min}$ in an Eppendorf model 3200 centrifuge. Of the supernatant $0.5 \mathrm{ml}$ was counted in scintillation fluid (Scintigel). Specific binding was measured as the difference in radioactivity present after dextran-charcoal treatment of the cytoplasmic fraction incubated in the presence and absence of nonradioactive hormone.

For assay of specific steroid uptake by nuclei, thymocytes were incubated with $5 \times 10^{-8} \mathrm{M}\left[{ }^{3} \mathrm{H}\right]$ dexamethasone for $30 \mathrm{~min}$ at $37^{\circ}$ with or without $25 \times 10^{-5} \mathrm{M}$ unlabeled dexamethasone. At the end of the incubation period, cells were sedimented (5 min, 150 $\left.\times g, 2^{\circ}\right)$ and washed with 500 volumes of TSS buffer. Nuclei were then purified by sucrose density centrifugation and lysed in formic acid. DNA concentration of the solution was measured and the radioactivity counted.

\section{ASSAY OF RNA POLYMERASE ACTIVITY}

The capacity of thymus nuclei to incorporate $\left[{ }^{3} \mathrm{H}\right] \mathrm{UMP}$ into acid-precipitable material after incubation with tritiated UTP was studied. The assay system contained, in a total volume of $150 \mu \mathrm{l}$ : thymus nuclei equivalent to $500 \mu \mathrm{g}$ DNA, $0.2 \mu \mathrm{mol}$ each ATP, GTP, and CTP, $0.002 \mu \mathrm{mol}$ UTP, $1 \mu \mathrm{Ci}$ tritiated UTP, $1.5 \mu \mathrm{mol}$ creatine phosphate, $5 \mu \mathrm{g}$ creatine phosphokinase, $1.5 \mu \mathrm{mol} \beta$-mercaptoethanol, $10 \mu \mathrm{mol}\left(\mathrm{NH}_{4}\right)_{2} \mathrm{SO}_{4}, 3$ $\mu \mathrm{mol} \mathrm{MgSO}_{4}, 10 \mu \mathrm{mol}$ Tris- $\mathrm{Cl}, \mathrm{pH} 7.9$. The reaction was terminated after an incubation period of $30 \mathrm{~min}$ at $37^{\circ}$ by pipetting $100 \mu \mathrm{l}$ aliquots on filter discs $\left(16 \mathrm{~cm}^{2}\right.$, Schleicher und Schuell 2043 b) and precipitating in $5 \%$ ice-cold trichloroacetic acid (TCA). Discs were washed four times in TCA and two times in $96 \%$ alcohol and then dried. The radioactivity was counted in toluene scintillation fluid. In order to determine $\left[{ }^{3} \mathrm{H}\right] \mathrm{UMP}$ incorporation into RNA in the presence of cytoplasm or polymerase $\mathrm{III}_{\mathrm{B}}$ containing column fractions the incubation medium was slightly modified. In a total volume of $190 \mu \mathrm{l}$ it contained: 100 $\mu \mathrm{l}$ column fraction or cytoplasm, $6 \mu \mathrm{mol} \mathrm{MnCl}_{2}, 0.3 \mu \mathrm{mol}$ ammonium sulfate, $16 \mu \mathrm{mol} \mathrm{MgCl}_{2}$, and $50 \mu \mathrm{g}$ calf thymus DNA instead of nuclei. All other constituents remained as in the system above. Polymerase $\mathrm{III}_{\mathrm{B}}$ of cytoplasm was purified by ion exchange chromatography as described by Seifart and Benecke (21) for rat liver cytosol. Activity of polymerase $\mathrm{III}_{B}$ in single column fractions was measured. The total activity was expressed as the sum of polymerase activity in each fraction per $\mu \mathrm{g}$ protein in the starting material. $\left[{ }^{3} \mathrm{H}\right] \mathrm{UMP}$ incorporation into RNA by intact thymus cells was measured after incubation of cell suspensions in TC 199 medium with or without dexamethasone for 45 $\mathrm{min}$ at $37^{\circ}$ followed by additional incubation for $30 \mathrm{~min}$ in the presence of tritiated UTP. Cells were then transferred to filter discs and the discs treated as described for nuclei.

Protein concentration was determined by the method of Lowry (14) with bovine serum albumin as standard. DNA was measured by the diphenylamine reaction according to the method of Burton (5) with calf thymus DNA as standard. The results are expressed as the mean value \pm SEM.

\section{RESULTS}

Between 14 and 70 days of age, the body weights of the animals rose from $20-160 \mathrm{~g}$ and the wet weights of the thymus glands rose steadily up to $0.33 \mathrm{~g}$. During further development the organ weight fell significantly $(P<0.01)$ to $0.266 \mathrm{~g}$ in 4 month-old rats weighing $290-300 \mathrm{~g}$. The ratio of thymus to body weight increased significantly up to 30 -day-old animals weighing $60 \mathrm{~g}$ and declined steadily during further development (Fig. 1). The protein to DNA ratio, a measure of cell size, was $2.8 \pm 0.5$ and remained constant during development.

The glucocorticoid binding capacity of the cytoplasmic fraction of thymus measured in vitro by incubation with $\left[{ }^{3} \mathrm{H}\right]$ dexamethasone rose significantly $(P<0.01)$ in rats weighing up to $125 \mathrm{~g}$ and subsequently decreased rapidly $(P<0.01)$ in animals with a body weight more than $160-180 \mathrm{~g}$. Incubation of intact thymocytes with radioactive hormone and subsequent purification of the nuclei revealed maximal specific hormone binding in 42-day-old rats weighing $90 \mathrm{~g}$. The reduction of the binding capacity in adult rats was less pronounced $(P<0.1)$ than the decrease of glucocorticoid receptor in the cytoplasmic fraction (Fig. 2).

After incubation of cells or cell fractions with $\left[{ }^{3} \mathrm{H}\right] \mathrm{UTP}$ in vitro RNA synthesis was measured by incorporation of radioactive UMP into the TCA-insoluble fraction. The nuclear RNA synthesizing activity decreased during development from $57 \pm 4.6$ $\mathrm{dpm} / \mu \mathrm{g} \mathrm{DNA}$ in young to $23 \pm 2.2 \mathrm{dpm} / \mu \mathrm{g}$ DNA in aging rats (Fig. 3). Incubation of cytoplasm with exogenous DNA as a template revealed a decrease of $\left[{ }^{3} \mathrm{H}\right]$ uridine incorporation into the acid-precipitable fraction from $36.6 \pm 5.5 \mathrm{dpm}$ in animals weighing $60 \mathrm{~g}$ to $28.7 \pm 1.3 \mathrm{dpm} / \mu \mathrm{g}$ protein in rats weighing $280 \mathrm{~g}(P<0.15)$. RNA polymerase $\mathrm{III}_{\mathrm{B}}$, a DNA-dependent RNA polymerase localized in cytoplasm, was purified by ion exchange chromatography of thymus cytosol. The total enzyme activity fell steadily during development and was reduced from

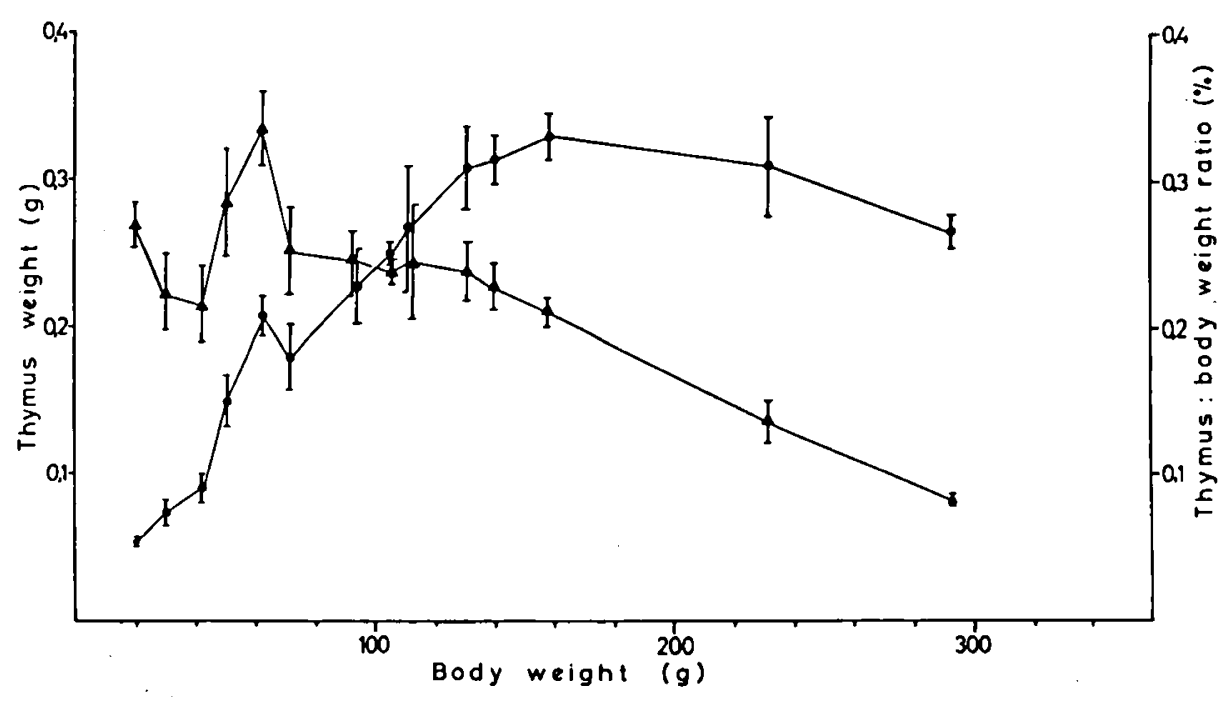

Fig. 1. Thymus weight (-@) and thymus to body weight ratio $(\boldsymbol{\Delta - \Delta})$ of the rat during development. Values represent the mean \pm SEM of 13-27 rats in each group of the indicated body weight. 
$22.7 \pm 2.5 \mathrm{dpm}$ in young rats to $16.4 \pm 2.2 \mathrm{dpm} / \mu \mathrm{g}$ of protein in the starting material in adult animals $(P=0.05)$. Whereas the activity of polymerase $\mathrm{III}_{\mathrm{B}}$ fell $27.8 \%$ during development, the RNA synthesizing activity of the whole cytoplasmic fraction fell $21.6 \%$ in the same animals.
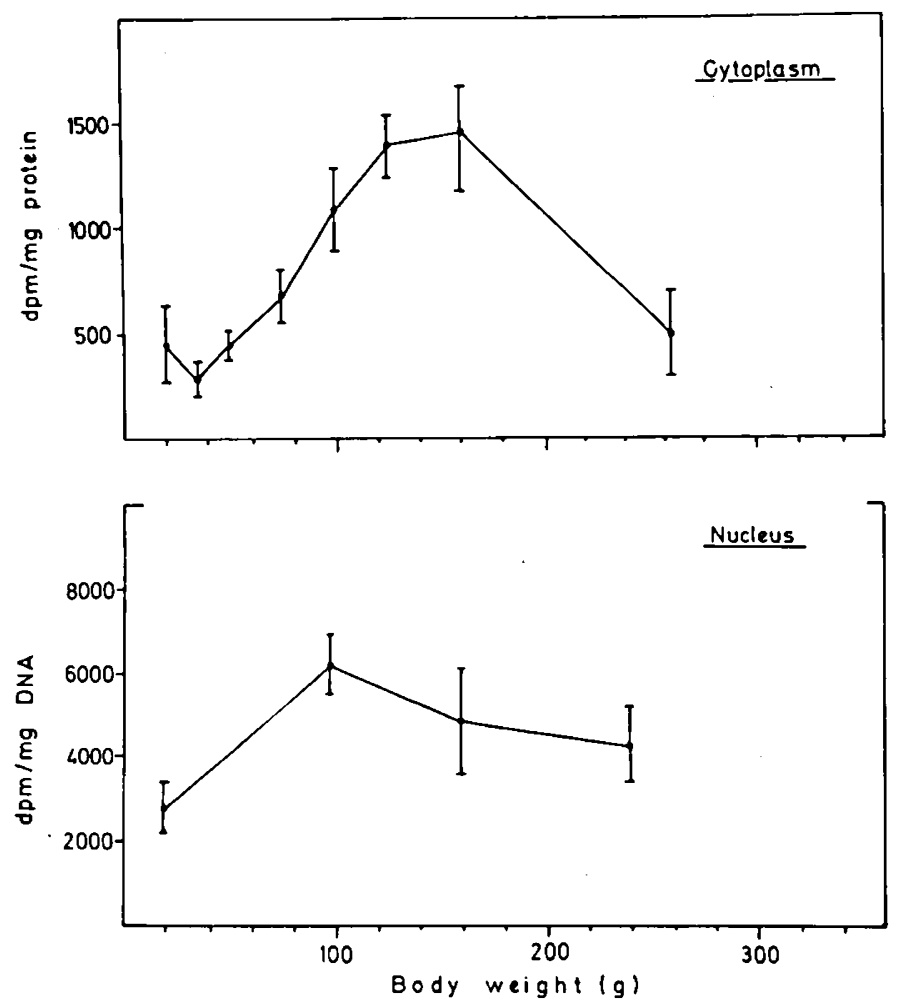

Fig. 2. Specific binding of $\left[{ }^{3} \mathrm{H}\right]$ dexamethasone to the cytoplasmic fraction and to nuclei of thymus cells during development. Tissue from two to four rats of each weight group was pooled for each experiment. Curves represent data from nine experiments (cytosol) and six experiments (nuclei). Mean \pm SEM.
Inhibition of in vitro RNA synthesis by glucocorticoids was studied in whole cells after in vitro hormone application and in isolated nuclei after intraperitoneal injection of $1 \mathrm{mg} / 100 \mathrm{~g}$ body weight of dexamethasone. After incubation of thymus cell suspensions with dexamethasone, depression of $\left[{ }^{3} \mathrm{H}\right] \mathrm{UMP}$ incorporation into the TCA-precipitable fraction revealed age-dependent changes. The inhibition increased in thymus cells of animals weighing up to $180 \mathrm{~g}$ and was reduced in cells of older animals. In vivo application of the hormone resulted also in an ageassociated reduction of nuclear RNA polymerase activities. Inhibition rose up to $39 \%$ in rats 8 weeks of age weighing $130 \mathrm{~g}$ and fell rapidly to $9 \%$ in animals 20 weeks of age weighing 300-350 $\mathrm{g}$ (Fig. 4). Inhibition of RNA polymerase $\mathrm{III}_{\mathrm{B}}$ by the hormone in the cytoplasmic fraction of the same animals (hormone application $3 \mathrm{hr}$ before death) was not significant. However, application

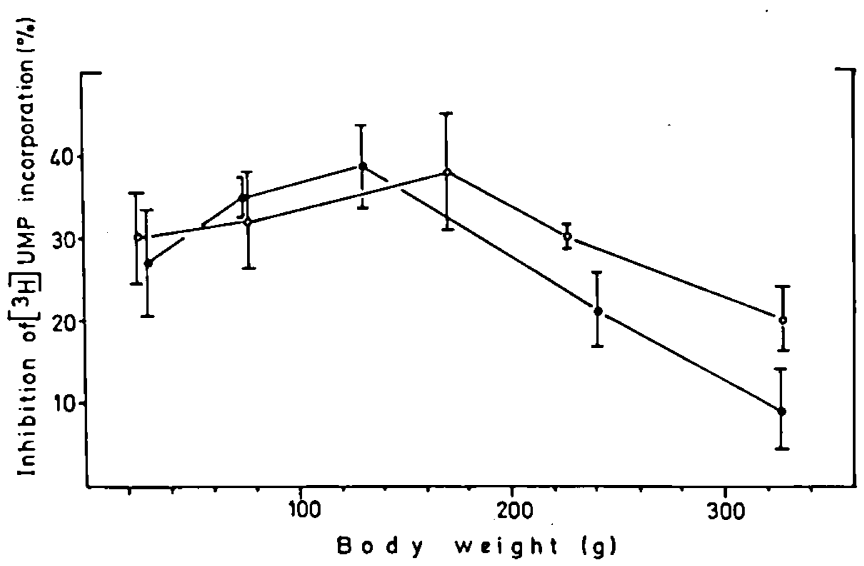

Fig. 4. Inhibition of RNA synthesizing activity by dexamethasone. Activity of isolated nuclei after application of dexamethasone in vivo (-); seven experiments with one to four animals of each weight group per experiment) and of isolated thymus cells after incubation with hormone in vitro $(\mathrm{O}-\mathrm{O}$; five experiments with two to three animals of each weight group per experiment). The differences between hormonetreated animals or cells and controls are plotted as percentage. Mean \pm SEM.

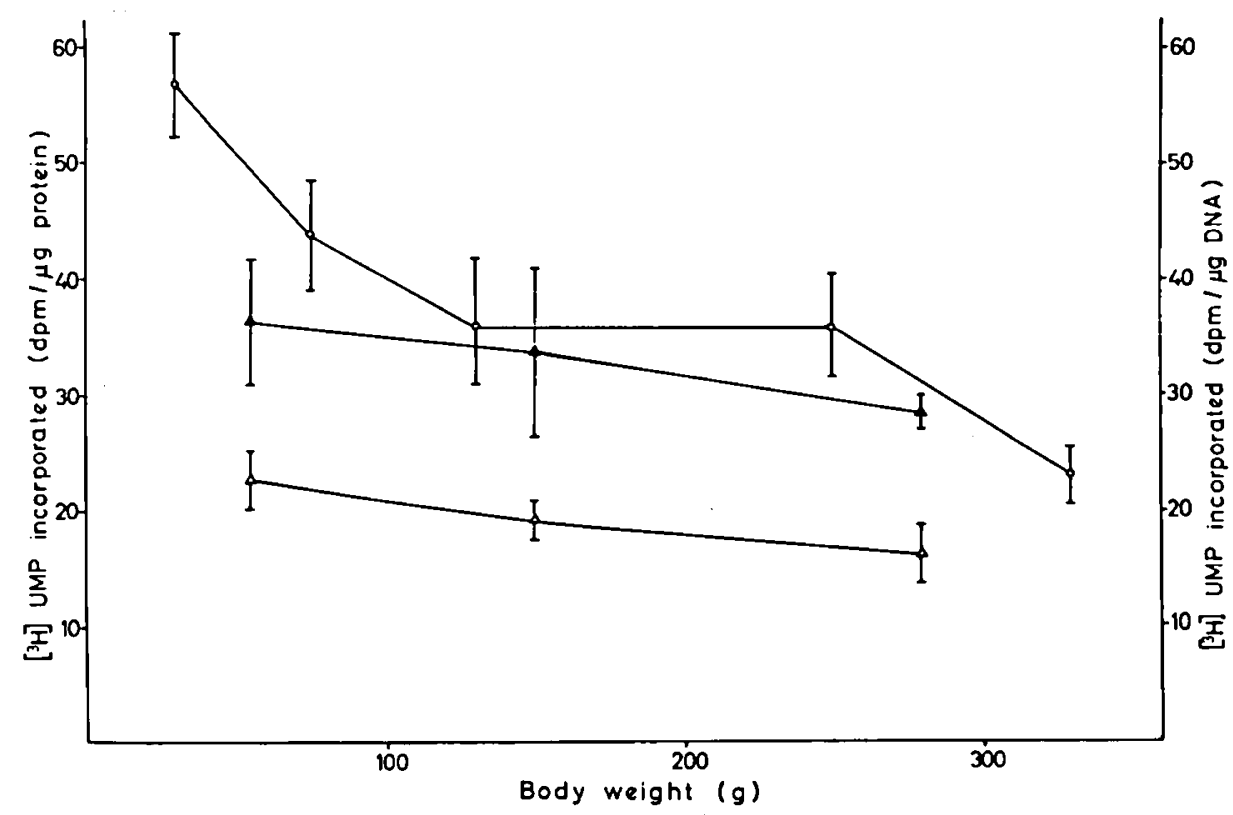

Fig. 3. RNA synthesizing activities of thymus cell fractions during development. $\left[{ }^{3} \mathrm{H}\right] \mathrm{UMP}$ incorporation into the acid-precipitable fraction in presence of isolated nuclei (O-O; eight experiments with one to four animals of each weight group per experiment) of the cytoplasmic fraction $\left(\Delta-\Delta ;\right.$ six experiments with three to five animals of each weight group per experiment), and of the cytoplasmic RNA polymerase III $I_{B}(\Delta-\Delta$; six experiments with three to four animals of each weight group per experiment). Mean \pm SEM. 


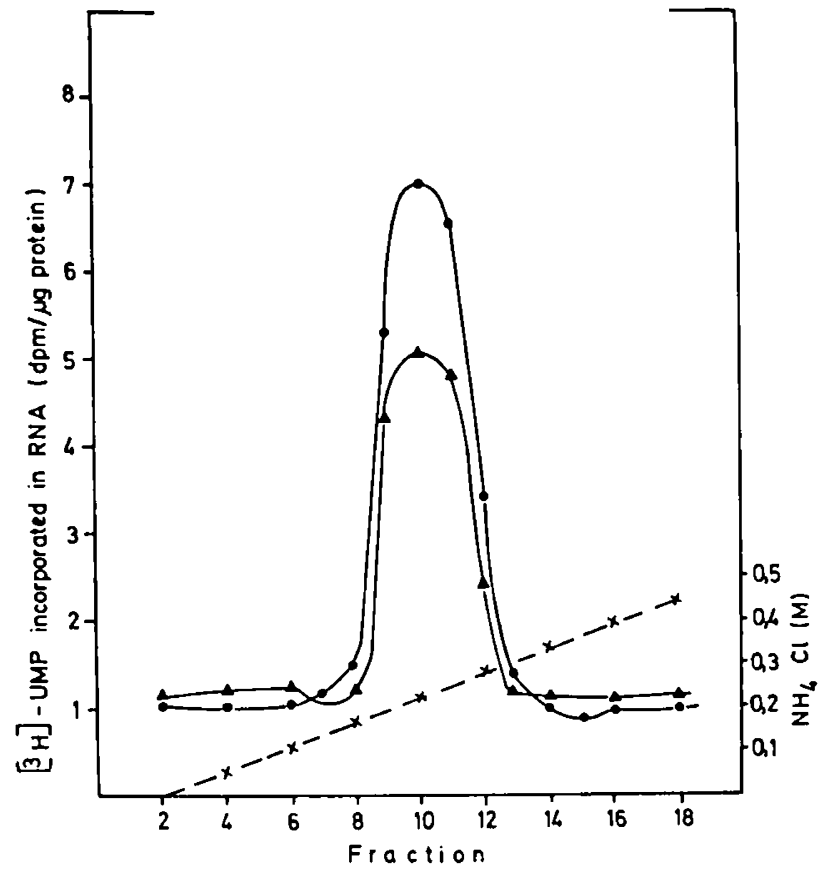

Fig. 5. DEAE-cellulose chromatography of RNA polymerase III $_{B}$ from rat thymus cytoplasm. The particulate-free cytosol was applied to a column, which was eluted with a linear gradient $(\times---x)$ from 0.0 to $0.6 \mathrm{M} \mathrm{NH}_{4} \mathrm{Cl}$ in buffer (0.05 M Tris, pH 7.5, $0.25 \mathrm{mM}$ EDTA, $5 \mathrm{mM} 2-$ mercaptoethanol, $20 \%$ glycerol). Enzyme activity in the column fractions (disintegrations per min per $\mu \mathrm{g}$ protein applied to the column) after in vivo application of dexamethasone $16 \mathrm{hr}$ before death $(\Delta-\Lambda)$ and of untreated animals (-) . Means of five experiments.

of dexamethasone to rats $16 \mathrm{hr}$ before killing resulted in a $37 \%$ decrease of polymerase $\mathrm{III}_{\mathrm{B}}$ activity (Fig. 5).

\section{DISCUSSION}

During development of the rat the thymus weight increases steadily until the animals have reached a weight of $160 \mathrm{~g}$. In older animals organ weight falls. The DNA to protein ratio however, as a measure of cell size, does not change. Therefore, the changes of organ weight are caused by reduction of cell number. Although mean organ weights were less and individual differences were greater in our animals than those described by McAnulty and Dickerson (16), the steady decrease of thymus to body weight ratio in animals weighing more than $60 \mathrm{~g}$ corresponds well to their results. Large individual differences of absolute and relative organ weights may be partly caused by different individual food uptake. Nutritional state affects thymus weight in humans (22) as well as in animals (16). Male rats have been mainly used in our experiments to exclude possible sexlinked differences.

Specific binding of the synthetic glucocorticoid dexamethasone that is not metabolized in thymus cells (2) rises in the cytoplasmic fraction of rats weighing up to $120-160 \mathrm{~g}$ and then declines parallel to the decrease of relative organ weight. In contrast to these changes of binding capacity in thymus cytosol, adult levels of glucocorticoid binding in rat liver cytosol are reached some days after birth and do not change during turther development (18). Cell size, which may influence glucocorticoid binding in lymphatic tissues (9), does not change significantly during development. Therefore, decrease of glucocorticoid binding may be explained by a relative increase of glucocorticoid-resistant cell lines or by changes of binding capacities of sensitive cell lines.

Binding of glucocorticoids to cytoplasmic proteins enhances nuclear hormone binding $(1,12)$. In contrast to other glucocorticoid target tissues, in thymocytes and lymphocytes there may. exist a second intranuclear localized glucocorticoid receptor protein (17). Therefore, the differences in developmental changes of receptor capacities between nucleus and cytoplasm may be caused by a glucocorticoid receptor primarily localized in the nucleus.

The in vitro RNA synthesizing capacity of isolated nuclei reflects the activity of nuclear RNA polymerase I, II, and III $_{A}$ and declines steadily during development. Purified cytoplasmic polymerase $\mathrm{III}_{\mathrm{B}}$ similarly falls with increasing body weight. This decrease of RNA synthesizing enzymes is easy to understand in adult animals with thymus involution but less understandable in young rats with a rapid rise of organ weight. Action of glucocorticoids seems to be not relevant for this reduction of RNA synthesis in untreated animals since glucocorticoid binding capacities are not correlated to the decline of RNA synthesizing activities during development. However, inhibition of uridine incorporation into RNA of thymocytes incubated with glucocorticoids in vitro reveals age-dependent changes that are well correlated with the hormone binding of the cells. This could be caused by a different cellular uptake of radioactive nucleotides in the presence of glucocorticoids (19). We therefore measured RNA polymerase activity in isolated nuclei after in vivo application of dexamethasone and found the strongest inhibition of RNA synthesis in thymus nuclei of animals weighing $130 \mathrm{~g}$. As only nuclear RNA polymerase $\mathrm{I}$ is affected by glucocorticoids (8), the age-dependent differences of hormone effect could be caused by change of polymerase I to II ratio. However, there is a striking parallelism between inhibition of nuclear RNA synthesis and glucocorticoid binding capacity in thymus cells. Therefore, we assumed that the different hormone effect is caused directly by changes of glucocorticoid receptor concentrations during development. Activity of cytoplasmic polymerase $\mathrm{III}_{\mathrm{B}}$ does not change significantly when measured $3 \mathrm{hr}$ after dexamethasone application, a time course sufficient to depress nuclear RNA synthesizing activity. However, even $16 \mathrm{hr}$ after hormone application activity of polymerase $\mathrm{III}_{\mathrm{B}}$ was significantly depressed. Whether inhibition of this enzyme is age dependent as well will have to be determined.

Developmental changes of glucocorticoid binding in rat thymus cells and correspondent inhibition of DNA-dependent RNA polymerases after hormone application indicate a functional role of these hormone receptors. Similar correlations were recently found by G. S. Roth (19) in rat splenic leukocytes of adult and aging rats. In thymus as well as in spleen decrease of glucocorticoid binding may be caused by increase of steroid-resistant cell lines. Therefore, the questions of whether and of how the synthesis of glucocorticoid receptor proteins can be induced in these cells arise.

\section{CONCLUSION}

Cytoplasmic and nuclear dexamethasone binding capacities of rat thymus cells are age-dependent. RNA synthesizing activities of isolated nuclei, of cytoplasmic fraction, and of cytoplasmic RNA polymerase $\mathrm{III}_{\mathrm{B}}$ decline during rat development. Inhibition of RNA synthesis by glucocorticoids is well correlated to age-associated changes of dexamethasone binding.

\section{REFERENCES AND NOTES}

1. Abraham, A. D., and Sekeris, C. E.: Corticosteroid binding macromolecules in the nucleus and cytosol of rat thymus cells. Biochim. Biophys. Acta, 297: 142 (1973).

2. Augustyn, J. M., and Brunkhorst, W. K.: Studies of corticosterone binding and metabolism in rat thymocytes. Biochim. Biophys. Acta, 264: 557 (1972).

3. Baxter, J. D., Harris, W. A., Tomkins, G. M., and Cohn, M.: Glucocorticoid receptors in lymphoma cells in culture: Relationship to glucocorticoid killing activity. Science, 171: 189 (1971).

4. Beato, M., Schmid, W., and Sekeris, C. E.: Two cortisol binding proteins from rat liver cytosol. Biochim. Biophys. Acta, 263: 764 (1972).

5. Burton, K.: A study on conditions and mechanism of the diphenylamine reaction for the colorimetric estimation of deoxyribonucleic acid. Biochem. J., 62: 315 (1956).

6. Cake, M. H., Ghisalberti, A. V., and Oliver, I. T.: Cytoplasmic binding of 
dexamethasone and induction of tyrosine aminotransferase in neonatal rat liver. Biochem. Biophys. Res. Commun. 54: 983 (1973).

7. Chambon, P.: Eukariotic nuclear RNA polymerase:Ann. Rev. Biochem., 44: 613 (1975).

8. Drews, J., and Wagner, L.: The effect of prednisolone injected in vivo on RNA polymerase activities in isolated rat thymus nuclei. Eur. J. Biochem., 13: 231 (1970).

9. Eurenius, K., Dalton, T. V., Lokey, H. J., and McIntyre, O. R.: The mechanism of glucocorticoid action on the PHA-stimulated lymphocyte. Biochim. Biophys. Acta, 177: 572 (1969)

10. Hofert, J. F., and White, A.: Effect of a single injection of cortisol, administered in vivo, on the in vitro incorporation of DNA and RNA precursors by rat thymus cells. Mol. Pharmacol., 3: 219 (1967).

11. Kirkpatrick, A. F., Kaiser, N., Milholland, R. J., and Rosen, F.: Glucocorticoid-binding macromolecules in normal tissues and tumors. J. Biol. Chem. 247: 70, (1972).

12. Lipp, K., van der Meulen, N., and Linneweh, F.: Dexamethason-bindung von Lymphocyten aus Blut und Milz und von Thymocyten. Pädiat. Pädol. (In press.)

13. Litwack, G., Filler, R., Rosenfeld, S. A., Lichtash, N., Wishman, A. C., and Singer, S.: Liver cytosol corticosteroid binder II, a hormone receptor. J. Biol. Chem., 193: 265 (1973).

14. Lowry, O. H., Rosebrough, N. J., Farr, A. L., and Randall, R. J.: Protein measurement with Folin phenol reagent. J. Biol. Chem., 193: 265 (1951).

15. Makman, M. W., Dvorkin, B., and White, A.: Alteration in protein and nucleic acid metabolism of thymocytes produced by adrenal steroids in vitro. J. Biol. Chem., 241: 1646 (1966)

16. McAnulty, P. A., and Dickerson, J. W. T.: The cellular response of the weanling rat thymus gland to undernutrition and rehabilitation. Pediat. Res. 9: 778 (1973).

17. van der Meulen, N., Abraham, A. D., and Sekeris, C. E.: Role of the nuclear cortisol binding protein in the control of transcription of thymocyte nuclei by cortisol. FEBS Lett., 25: 116 (1972).

18. van der Meulen, N., Lipp, K., and Sekeris, C. E.: Postnatale Adaptation und ihre hormonelle Kontrolle. Klin. Wschr., 52: 571 (1974).

19. Roth, G. S.: Age-related changes in glucocorticoid binding by rat splenic leukocytes: Possible cause of altered adaptive responsiveness. Fed. Proc., 34: 183 (1975).

20. Schaumburg, B. P.: Studies of the glucocorticoid-binding protein from thymocytes. I. Localization in the cell and some properties of the protein. Biochim. Biophys. Acta, 214: 520 (1970).

21. Seifart, K. H., and Benecke, B. J.: DNA-dependent RNA polymerase C: Occurrence and localization in various animal cells. Eur. J. Biochem., 53: 293 (1975).

22. Smythe, P. M., Schonland, M., Brereton-Stiles, G. G., Coovadia, H. M., Grace, H. J., Loening, W. E. K., Mafoyane, A., Parent, M. A., and Vos, G. H.: Thymolymphatic deficiency and depression of cell-mediated immunity in protein-calorie malnutrition. Lancet, ii: 939 (1971).

23. Werthamer, S., Samuels, A. J., and Amaral, L.: Identification and partial purification of transcortin-like protein within human lymphocytes. J. Biol. Chem. 248: 6398 (1973).

24. Wira, C., and Munck, A.: Specific glucocorticoid receptors in thymus cells. J. Biol. Chem., 245: 3436 (1970).

25. Whitfield, J. F., Perris, A. D., and Yondale, T.: Destruction of nuclear morphology of thymic lymphocytes by the corticosteroid cortisol. Exp. Cell Res., 52: 349 (1968).

26. Hanover, Germany.

27. Amersham, England.

28. Grand Island, N.Y.

29. Uppsala, Sweden.

30. Maidstone, England.

31. Heidelberg, Germany.

32. Karlsruhe, Germany.

33. Darmstadt, Germany.

34. Mannheim, Germany.

35. The authors gratefully acknowledge the skilled technical assistance of Miss $R$. Stössel and Mrs. G. Wenske.

36. This research was supported by the Deutsche Forschungsgemeinschaft.

37. Requests for reprints should be addressed to: K. Lipp, M.D., UniversitätsKinderklinik, Humboldtallee 38, 34 Göttingen (West Germany).

38. Received for publication July $18,1976$.

39. Accepted for publication October $8,1976$.

\title{
Rapid Eye Movement Sleep, Motoneurone Inhibition, and Apneic Spells in Preterm Infants
}

\author{
FRANZ J. SCHULTE, ${ }^{28}$ CORD BUSSE, AND WALTRAUD EICHHORN
}

Department of Pediatrics II, University of Göttingen, West Germany

\section{Summary}

Not principally different from the results obtained in more mature subjects, monosynaptic reflex excitability of spinal motoneurones in preterm infants decreases during active sleep. However, in preterm infants the electric reflex response is not abolished, and is not even continuously depressed during the entire active sleep period. Spinal motoneurone inhibition is demonstrable only during certain periods of active sleep, and it is during this state of decreased spinal motoneurone excitability when apneic spells predominantly occur.

\section{Speculation}

The concept of apneic spells being promoted by rapid eye movement (REM) sleep brain mechanisms, as outlined by Gabriel $e t$ al. (10) and supported by data of this study, can so far mainly explain respiratory pauses in otherwise healthy preterm infants. However, in neonatal sepsis, meningitis, hypoxia, hypo- glycemia, etc., the same central nervous system inhibitory processes should increase the risk of apneic spells, provided that active sleep states still exist. Furthermore, Bryan and Bryan (2) have demonstrated a considerable thoracic wall instability during active sleep, which is probably also due to inhibition of spinal motoneurones innervating intercostal muscles. Thus, when respiratory brain stem centers are partly damaged, tonic spinal motoneurone inhibition during active sleep can additionally increase the infant's difficulty in maintaining sufficient respiration.

\footnotetext{
"REMS is a time of profound motor paralysis in which tendon reflexes cannot be elicited and in which voluntary movement is impossible" (W. Dement, 1972 (4))-otherwise our dreams would have serious consequences.
}

There is increasing evidence in the literature that in infants short respiratory pauses $(25)$ and periodic breathing $(8,20)$, as well as apneic spells with and without bradycardia $(9-11,17)$ 